\title{
Studies on Linseed (Linum usitatissimum L.) based Intercropping Systems as Influenced by Integreted Nutrient Management on Yield and Economics under Moisture Scarce Condition
}

\author{
Amar Kant Verma*, P.N. Yadav and U.D. Awasthi \\ Department of Soil Conservation and Water Management, C S Azad University of Agriculture \\ and Technology, Kanpur-208002 (U.P.), India \\ *Corresponding author
}

\section{A B S T R A C T}

\section{Keywords \\ Rainfed, Integrated nutrient management, \\ Equivalent yield, Land equivalent ratio, \\ Vermicompost. \\ Article Info \\ Accepted: \\ 17 September 2017 \\ Available Online: \\ 10 November 2017}

A field experiment was conducted during rabi seasons of 2015-16 and 2016-17 at Soil Conservation and Water Management Farm of C S Azad University of Agriculture and Technology, Kanpur to find out suitable row ratio of linseed + lentil/barley in intercropping systems under rainfed condition. The results revealed that linseed performed better in intercropping than sole cropping. Among different cropping systems, linseed + lentil (3:1) exhibited maximum linseed equivalent yield of 13.33 and $12.11 \mathrm{q} \mathrm{ha}^{-1}$ and earned maximum net return of Rs. 33204 and 30104 respectively, during the two years of experimentation.

\section{Introduction}

With growing population the demand of water for various purposes is ever increasing. On the other hand, the availability of water resources is limited in space and time. A systematic and scientific planning for its optimal utilization is high imperative. The scarcity of water regarded as the most important factors in crop production, is usually a limiting factor in semi-arid regions. To meet the future food demands for water among various sectors, a more efficient use of water will be essential (Bhatt et al., 2016).

The integrated nutrient management has now gaining importance because of the present negative balance and neither the chemical fertilizers alone nor the potential alternative source of nutrient can achieve the production sustainability of soils and crops under intensive cultivation.

Under such conditions integration of indigenously available organic sources of nutrients with inorganic sources is of vital significance for sustaining the productivity and fertility of soil (Sharma and Saroa, 2017). Vermicompost is a good organic source of plant nutrient and growth hormone which enhance plant growth and microbial population (Awasthi et al., 2011). 
Inoculation of biofertilizers (PSB) reduce the use of inorganic fertilizers with a view to attain an ecofriendly environment. Significant advantages in land use efficiency, crop productivity and monetary returns in intercropping as compared with sole cropping of component crops have been recorded under varied agroclimatic conditions (Singh et al., 2008, Rehman et al., 2009 and Singh et al., 2011). The role of balanced use of organic and inorganic fertilizers in boosting productivity is well known. However, such information is lacking in the sub-tropical rainfed agroecosystems of Uttar Pradesh.

Henceforth this study was undertaken to evaluate the suitable cropping pattern, nitrogen fertilization and standardization of vermicompost doses in the region besides their optimal combination of the monetary and non-monetary inputs on productivity of rainfed crops.

\section{Materials and Methods}

A field experiment was conducted during rabi seasons of 2015-16 and 2016-17 at Soil Conservation and Water Management Farm of C S Azad University of Agriculture and Technology, Kanpur in alluvial soil under rainfed condition. The soil of the experimental field was sandy loam in texture and slightly calcareous having organic carbon $0.32 \%$, total nitrogen $0.03 \%$, available $\mathrm{P}_{2} \mathrm{O}_{5}$ $16.0 \mathrm{~kg} \mathrm{ha}^{-1}$, available $\mathrm{K}_{2} \mathrm{O} 155 \mathrm{~kg} \mathrm{ha}^{-1}, \mathrm{pH}$ 7.7, electrical conductivity $0.37 \mathrm{dS} \mathrm{m} \mathrm{m}^{-1}$, wilting point $6.2 \%$, field capacity $18.4 \%$, water holding capacity $29.6 \%$, Bulk density $1.46 \mathrm{Mg} \mathrm{m}^{-1}$, Particle density $2.56 \mathrm{Mg} \mathrm{m}^{-1}$ and porosity $42.9 \%$. The field experiment was conducted in split plot design with three replications, keeping cropping systems in main plots and INM in subplots. The treatment comprising 9 cropping systems viz.

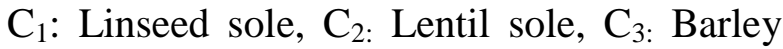
sole, $\mathrm{C}_{4}$ : Linseed + lentil $(3: 1), \mathrm{C}_{5}$ : Linseed + barley (3:1), $\mathrm{C}_{6}$ : Linseed + lentil $(4: 1), \mathrm{C}_{7}$ :
Linseed + barley (4:1), $\mathrm{C}_{8}$ : Linseed + lentil (5:1) and $\mathrm{C}_{9 \text { : }}$ Linseed + barley (5:1) and 3 integrated nutrient management viz. $\mathrm{N}_{1}$ : RDN, $\mathrm{N}_{2}: 75 \%$ RDN through inorganic $+25 \%$ RDN through vermicompost $\mathrm{N}_{3}: 75 \% \mathrm{RDN}$ through inorganic $+25 \%$ RDN through vermicompost + bio-fertilizer (seed coating) + PSB @ $2.5 \mathrm{~kg}$ ha $^{-1}$ in soil. Linseed cv Padmini, lentil cv K75 and barley cv Haritma was grown $25 \mathrm{~cm}$ apart. Crops were sown on 20.11.2015 and 26.11.2016 whereas linseed was harvested on 30.03.2016 and 03.04.2017, lentil 04.04.2016 and 06.04.2017 and barley on 26.03.2016 and 01.04.2017 during the first and second year of experimentation, respectively. Available moisture at sowing time up to $100 \mathrm{~cm}$ soil profile was measured which was 281.7 and $277.5 \mathrm{~mm}$. The amount and disribution of rainfall received during cropping season was 49.9 and $32.8 \mathrm{~mm}$ in 2015-16 and 2016-17, respectively against the average annual rainfall of about $800 \mathrm{~mm}$. Recommended package of practices and fertilizers doses were applied in different treatments.

Cost of cultivation was calculated by taking in to account the prevailing prices of the inputs. The minimum support price for the grains of linseed, lentil and barley were taken in to account over the years and used for computing linseed equivalent ratio as per (Willey, 1979). The economic efficiency in terms of Rs. ha ${ }^{-1}$ day $^{-1}$ was worked out by dividing the total net monetary returns by total duration of the crops. The economics of various cropping systems was also worked out to assess the most viable and remunerative cropping systems under rainfed condition.

\section{Results and Discussion}

The information on seed yield of linseed, lentil and barley as well as linseed equivalent yield for different treatments indicated that the seed yield was significantly influenced by the different treatments over the periods of experimentation (Table 1). 
Table.1 Effect of Cropping systems and INM on yield of component crops and equivalent yield

\begin{tabular}{|c|c|c|c|c|c|c|c|c|}
\hline \multirow[t]{3}{*}{ Treatment } & \multicolumn{6}{|c|}{ Seed yield $\left(q\right.$ ha $\left.^{-1}\right)$} & \multicolumn{2}{|c|}{$\begin{array}{c}\text { Linseed equivalent } \\
\text { yield } \\
\left.(\mathbf{q ~ h a})^{-1}\right) \\
\end{array}$} \\
\hline & Linseed & Lentil & Barley & Linseed & Lentil & Barley & 2015-16 & 2016-17 \\
\hline & \multicolumn{3}{|c|}{ 2015-16 } & \multicolumn{3}{|c|}{ 2016-17 } & & \\
\hline \multicolumn{9}{|l|}{ Cropping systems: } \\
\hline $\mathbf{C}_{1}$ Linseed sole & 10.61 & - & - & 9.66 & - & - & 10.61 & 9.66 \\
\hline $\mathbf{C}_{2}$ Lentil sole & - & 11.82 & - & - & 11.41 & - & 8.93 & 7.70 \\
\hline $\mathbf{C}_{\mathbf{3}}$ Barley sole & - & - & 23.85 & - & - & 23.12 & 6.64 & 5.84 \\
\hline $\mathbf{C}_{4}$ Linseed + lentil (3:1) & 9.72 & 4.78 & - & 9.10 & 4.47 & - & 13.33 & 12.11 \\
\hline $\mathbf{C}_{5}$ Linseed + barley $(3: 1)$ & 8.94 & - & 8.47 & 8.47 & - & 8.31 & 11.29 & 10.56 \\
\hline $\mathbf{C}_{6}$ Linseed + lentil (4:1) & 9.18 & 4.13 & - & 8.96 & 3.89 & - & 12.30 & 11.58 \\
\hline $\mathbf{C}_{7}$ Linseed + barley $(4: 1)$ & 8.62 & - & 7.68 & 8.29 & - & 7.49 & 10.76 & 10.18 \\
\hline $\mathbf{C}_{8}$ Linseed + lentil (5:1) & 9.00 & 3.89 & - & 8.60 & 3.47 & - & 11.94 & 10.94 \\
\hline C9 Linseed + barley $(5: 1)$ & 7.98 & - & 7.29 & 7.58 & - & 6.86 & 10.00 & 9.31 \\
\hline SE (d) & 0.29 & 0.14 & 0.64 & 0.44 & 0.32 & 0.59 & 0.28 & 0.37 \\
\hline $\mathrm{CD}(\mathrm{P}=0.05)$ & 0.64 & 0.36 & 1.60 & 0.96 & 0.80 & 1.47 & 0.59 & 0.78 \\
\hline \multicolumn{9}{|c|}{ B. Integrated nutrient management: } \\
\hline $\mathbf{N}_{1} R D N$ & 8.48 & 5.69 & 10.62 & 7.78 & 5.33 & 9.69 & 9.75 & 8.90 \\
\hline $\begin{array}{l}\mathbf{N}_{2} 75 \% \text { RDN through inorganic }+ \\
25 \% \text { RDN through vermicompost }\end{array}$ & 9.12 & 6.13 & 11.80 & 8.62 & 5.78 & 11.49 & 10.62 & 9.73 \\
\hline $\begin{array}{l}\mathbf{N}_{3} 75 \% \text { RDN through inorganic }+ \\
25 \% \text { RDN through vermicompost } \\
+ \text { bio-fertilizer (seed coating) + } \\
P S B @ 2.5 \mathrm{~kg} \mathrm{ha}^{-1} \text { in soil. }\end{array}$ & 9.85 & 6.65 & 13.05 & 9.59 & 6.31 & 13.15 & 11.59 & 10.69 \\
\hline SE (d) & 0.17 & 0.23 & 0.40 & 0.19 & 0.29 & 0.34 & 0.16 & 0.19 \\
\hline $\mathrm{CD}(\mathrm{P}=0.05)$ & 0.36 & 0.50 & 0.85 & 0.38 & 0.63 & 0.73 & 0.32 & 0.39 \\
\hline
\end{tabular}


Table.2 Effect of Cropping systems and INM on LER and economics under different treatments

\begin{tabular}{|c|c|c|c|c|c|c|c|c|}
\hline \multirow[t]{2}{*}{ Treatment } & \multicolumn{2}{|c|}{ LER } & \multicolumn{2}{|c|}{$\begin{array}{l}\text { Net return } \\
\left(\operatorname{Rs~ha}^{-1}\right)\end{array}$} & \multicolumn{2}{|c|}{$\mathrm{B}: \mathrm{C}$ ratio } & \multicolumn{2}{|c|}{$\begin{array}{l}\text { Economic efficiency } \\
\left(\operatorname{Rs~ha}^{-1} \text { day }^{-1}\right)\end{array}$} \\
\hline & 2015-16 & 2016-17 & 2015-16 & 2016-17 & 2015-16 & 2016-17 & 2015-16 & 2016-17 \\
\hline \multicolumn{9}{|l|}{ Cropping systems: } \\
\hline $\mathbf{C}_{1}$ Linseed sole & 1 & 1 & 20024 & 15420 & 1.62 & 1.42 & 151.69 & 119.53 \\
\hline $\mathbf{C}_{2}$ Lentil sole & 1 & 1 & 14483 & 10201 & 1.43 & 1.29 & 106.49 & 77.28 \\
\hline $\mathbf{C}_{\mathbf{3}}$ Barley sole & 1 & 1 & 22684 & 17755 & 1.68 & 1.50 & 178.61 & 139.80 \\
\hline $\mathbf{C}_{4}$ Linseed + lentil (3:1) & 1.32 & 1.33 & 33204 & 30104 & 1.98 & 1.84 & 123.89 & 115.34 \\
\hline $\mathbf{C}_{5}$ Linseed + barley $(3: 1)$ & 1.19 & 1.23 & 30812 & 28106 & 1.92 & 1.77 & 118.96 & 109.78 \\
\hline $\mathbf{C}_{6}$ Linseed + lentil (4:1) & 1.21 & 1.26 & 28748 & 27003 & 1.86 & 1.75 & 107.26 & 103.4 \\
\hline $\mathbf{C}_{7}$ Linseed + barley $(4: 1)$ & 1.13 & 1.18 & 28038 & 24945 & 1.85 & 1.68 & 108.25 & 97.44 \\
\hline $\mathbf{C}_{8}$ Linseed + lentil (5:1) & 1.17 & 1.19 & 26651 & 22814 & 1.79 & 1.62 & 99.44 & 87.40 \\
\hline C $_{9}$ Linseed + barley $(5: 1)$ & 1.05 & 1.08 & 23732 & 21353 & 1.72 & 1.61 & 91.62 & 83.41 \\
\hline SE (d) & 0.04 & 0.05 & - & - & - & - & - & - \\
\hline $\mathrm{CD}(\mathrm{P}=0.05)$ & 0.09 & 0.10 & - & - & - & - & - & - \\
\hline \multicolumn{9}{|c|}{ B. Integrated nutrient management: } \\
\hline $\mathbf{N}_{1} R D N$ & 1.06 & 1.07 & 22293 & 18012 & 1.72 & 1.53 & 95.28 & 83.85 \\
\hline $\begin{array}{l}\mathbf{N}_{2} 75 \% \text { RDN through inorganic }+ \\
25 \% \text { RDN through vermicompost }\end{array}$ & 1.16 & 1.19 & 25111 & 21429 & 1.75 & 1.59 & 115.78 & 103.79 \\
\hline $\begin{array}{l}\mathbf{N}_{3} 75 \% \text { RDN through inorganic }+ \\
25 \% \text { RDN through vermicompost } \\
+ \text { bio-fertilizer (seed coating) + } \\
P S B @ 2.5 \mathrm{~kg} \mathrm{ha}^{-1} \text { in soil. }\end{array}$ & 1.25 & 1.30 & 29108 & 26457 & 1.83 & 1.70 & 150.65 & 123.47 \\
\hline $\mathrm{SE}(\mathrm{d})$ & 0.02 & 0.03 & - & - & - & - & - & - \\
\hline $\mathrm{CD}(\mathrm{P}=0.05)$ & 0.04 & 0.05 & - & - & - & - & - & - \\
\hline
\end{tabular}


Sole cropping showed significantly higher yield as compared to intercropping treatments. However, linseed equivalent yield was significantly highest under linseed + lentil (3:1) followed by linseed + lentil (4:1) whereas lowest equivalent yield was obtained in the treatment of linseed + barley $(5: 1)$ among different cropping systems during two different years. Application of $75 \%$ RDN through inorganic $+25 \%$ RDN through vermicompost + biofertilizer (seed coating) + PSB @ $2.5 \mathrm{~kg} \mathrm{ha}^{-1}$ in soil brought about significantly highest seed yield and lowest values under RDN as well as linseed equivalent yield might be due to integrated application of fertilizers and organic sources has been also reported by Dubey et al., (2015).

Land equivalent ratio (LER) of all treatments of cropping systems was more than unity (Table 2). It was due to beneficial effect of intercropping on productivity of component crops. Treatment of linseed + lentil (3:1) attained highest values (1.32 and 1.33) than other cropping systems during both the years which might be due to comparatively higher productivity of the system. Better utilization of land and growth resources by the crops in intercropping systems has also been reported by Sharma, and Goswami (2010).

The maximum net return of Rs. 33204 and 30104 was fetched by linseed + lentil (3:1) followed by linseed + barley (3:1) Rs. 30812 and 28106 under different treatments of cropping systems (Table 2). It may be attributed due to linseed equivalent yield in different row crop adjustments during the two years of study. Subsequently, B:C ratio varied from 1.62 to 1.98 and 1.84 to 1.42 during the two years of experimentation, highest and lowest values were recorded in linseed + lentil, (3:1) and lentil sole, respectively. The application of INM further influenced the B: $\mathrm{C}$ ratio and values ranged from 1.72 to 1.83 and 1.53 to 1.70 lowest and highest values were observed in $\mathrm{N}_{1}$ and $\mathrm{N}_{3}$, respectively (Nikam et al., 2008). Economic efficiency of different treatments further proved the potential of different cropping systems as well as application of INM. The scrutiny of the data clearly indicate that economic efficiency was maximum (Rs178.61 $\mathrm{ha}^{-1} \mathrm{day}^{-1}$ ) in the treatment of linseed + lentil (3:1) and minimum (Rs $139.80 \mathrm{ha}^{-1} \mathrm{day}^{-1}$ ) under linseed + barley (5:1) during the two different years.

Based on two years of experiment it may be inferred that linseed + lentil (3:1) supplemented with 75\% RDN through inorganic $+25 \% \mathrm{RDN}$ through vermicompost + biofertilizer (seed coating) + PSB @ $2.5 \mathrm{~kg}$ $\mathrm{ha}^{-1}$ in soil showed good potential for sustainable production and proved to be quite remunerative in rainfed alluvial tract of Uttar Pradesh.

\section{Acknowledgement}

The author would like to express gratitude to Department of Science and Technology, Govt. of India, New Delhi for providing fellowship as an opportunity to commence his $\mathrm{Ph} . \mathrm{D}$. programme in Soil Conservation \& Water Management.

\section{References}

Awasthi, U.D.; Dubey, S.D. and Shripal (2011). Effect of nitrogen and moisture conservation practices on yield, uptake water use efficiency and quality of linseed. Indian Journal of Agricultural Sciences, 81 (4): 383-385.

Bhatt, R., Arora, Sanjay and Chew, Clara, C. (2016). Improving irrigation water productivity using Tensiometers. Journal of soil and water conservation. 15 (2): 12-124.

Dubey, S.D.; Diwakar, A.K.; Tripathi, A.K.; Tiwari, U.S. and Pandey, R. (2015). 
Response of linseed (Linum usitatissium

L.) and Indian mustard (Brassica juncea

L.) to integrated nutrient management in Central plain zone of Uttar Pradesh. Current advances in Agricultural Science, 7 (1): 62-64.

Kumar Kailash, Adak, T. and Singh, V.K. (2017). Green manuring and nutrient management impacting soil properties and sustainability of mango orchard. Journal of soil and water comservation. 16 (1): 72-78.

Nikam, R.R.; Deshpande, R.M. and Yenprendiwar, M.D. (2008). Studies on fertilizer management in linseed based intercropping system under rainfed condition. Journal of Soils and Crops, 8 (1): 158-161.

Rahman, M.M.; Awal, M.A.; Amin, A. and Parvej, M.R. (2009). Compatibility, growth and production potential of mustard/lentil intercrops. International Journal of Botany, 5 (1): 100-106.

Sharma, R.K. and Goswami, V.K. (2010). Comparative performance of chickpea and linseed in their pure and intercropping systems. Green farming, 1
(2): 128.

Sharma, S. and Saroa, G.S. (2017). Effect of organic and integrated nutrient management practices on soil phosphorus fractions and total phosphorus in basmati-wheat sequence. Journal of soil and water conservation. 16 (11): 79-85.

Singh, M.K.; Chitale, S.; Sarawgi, S.K.; Tiwari, A. and Jaiswal, V. (2011). Productivity, economics, nutrient status and weed studies in intercropping in Rabi cereal, legume, Oilseeds and spices on Inceptisols in Chhattisgarh plain, Journal of Soils and crops, 21 (2): 165-169.

Singh, U.; Sood, A.A.; Badrul Hasan, Singh, P. and Singh, S.R. (2008). Production potential and economics of intercropping of lentil with brown sarson and Oat. Indian Journal of Agronomy, 53 (2): 135-139.

Willey, R.W. (1979). Intercropping its importance and research needs. Part I competition and yield advantages field crop Abstracts 32: 1-19.

\section{How to cite this article:}

Amar Kant Verma, P.N. Yadav and Awasthi, U.D. 2017. Studies on Linseed (Linum usitatissimum L.) based Intercropping Systems as Influenced by Integreted Nutrient Management on Yield and Economics under Moisture Scarce Condition. Int.J.Curr.Microbiol.App.Sci. 6(11): 2309-2314. doi: https://doi.org/10.20546/ijcmas.2017.611.274 